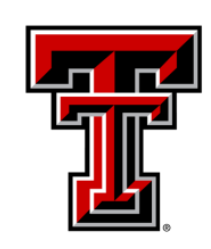

TEXAS TECH UNIVERSITY

Libraries"

\title{
DESOCIALIZATION OF TAXES: A TAXATION SYSTEM PROPOSAL FOR VENEZUELA
}

\section{The Texas Tech community has made this publication openly available. Please share how this access benefits you. Your story matters to us.}

\begin{tabular}{|l|l|}
\hline Citation & $\begin{array}{l}\text { Acevedo, R., Cirocco, L., \& Lorca-Susino, M. (2020). Desocialization } \\
\text { of taxes: A taxation system proposal for Venezuela. Estudios } \\
\text { Libertarios, 3, 1-30. }\end{array}$ \\
\hline Citable Link & $\underline{\text { https://hdl.handle.net/2346/86885 }}$ \\
\hline Terms of Use & $\underline{\text { CC-BY 4.0 }}$ \\
\hline
\end{tabular}




\title{
DESOCIALIZATION OF TAXES: A TAXATION SYSTEM PROPOSAL FOR VENEZUELA
}

\author{
Rafael Acevedo*, Luis Cirocco ${ }^{\Psi}$, and María Lorca-Susino ${ }^{\phi 1}$
}

\begin{abstract}
Venezuela requires a change in the economic, fiscal, and political system. Supported on the findings of Acevedo et al. (2020), we argue that the most important challenge is to reduce and starve the government and empower the citizens. This will be only possible through a new taxation system to eradicate the fiscal independency of the State. Following Rothbard (2018, 1992, and 1981) we have developed a proposal that would limit the State and any possibilities to intervene the natural flow of the free market. The paper presents a review of the history and evolution of the exponential increment of the tax burden that Venezuelans taxpayers have experienced through the years, and proposes a fiscal reform based on three main pillars: i) municipalization of the taxation structure; ii) simplification by elimination; and iii) imitate the market as suggested by Rothbard (1992). The main conclusion of this research is that this proposal restricts State's fiscal independence and eradicates the possibility that governments continue applying populist policies and boosting central planning.
\end{abstract}

Keywords: De-socialization; Privatization; Taxes; Venezuela.

JEL Codes: L33, B53

\footnotetext{
${ }^{*}$ Rafael Acevedo is Research Associate in the Free Market Institute at Texas Tech University. Founder-Director and CEO of Econintech. Corresponding author: rafael.acevedo@ttu.edu

${ }^{\Psi}$ Luis Cirocco is Lecturer at Universidad Centroccidental Lisandro Alvarado. Founder-Director of Econintech.

${ }^{\phi}$ María Lorca-Susino is Professor of Economics in the Business School at University of Miami. President of Econintech.

${ }^{1}$ Authors thank Dr. Hugo J. Faría, from University of Miami and Econintech, for providing very insightful comments and discussions on this proposal; Dr. Mark Thornton, from the Mises Institute, for his valuable suggestions, and time dedicated attending Cirocco during his stay in the Institute. Cirocco thanks to the Mises Institute for hosting and supporting him as researcher in residence while he worked on this paper. Acevedo thanks to the Free Market Institute at Texas Tech University and the Mises Institute for supporting him to attend the Libertarian Scholars Research Conference 2019 to present this research. We are indebted with Dr. Leonardo Vera Asaf, from Universidad Central de Venezuela, for providing his dataset to replicate some of the graph of his article. All errors or misunderstandings are solely responsibility of the authors.
} 
Receipt date: November 24, 2020.

Acceptance date: January 9, 2021.

Desocialización de impuestos: Una propuesta de un sistema tributario para Venezuela

\section{Resumen}

Venezuela requiere un cambio en el sistema económico, fiscal y político. Con base en los hallazgos de Acevedo et al. (2020), argumentamos que el desafío más importante es reducir sustancialmente el tamaño del gobierno para empoderar a los ciudadanos. Esto solo será posible a través de un nuevo sistema tributario orientado a la erradicación de la independencia fiscal del Estado. Siguiendo a Rothbard (2018, 1992 y 1981) hemos desarrollado una propuesta que limitaría al Estado y cualquier posibilidad de intervenir el flujo natural del libre mercado. El trabajo presenta una revisión de la historia y evolución del incremento exponencial de la carga tributaria que los contribuyentes venezolanos han experimentado a lo largo de los años, y propone una reforma fiscal basada en tres pilares principales: i) municipalización de la estructura tributaria; ii) simplificación por eliminación; e iii) imitar el mercado como sugiere Rothbard (1992). La principal conclusión de esta investigación es que esta propuesta restringe la independencia fiscal del Estado y erradica la posibilidad de que los gobiernos sigan aplicando políticas populistas e impulsando la planificación centralizada.

Palabras clave: Desocialización; Privatización; Impuestos; Venezuela.

Clasificación JEL: L33, B53

Fecha de recepción: 24 de noviembre de 2020.

Fecha de aceptación: 9 de enero de 2021. 
The State is the only legal institution in society that acquires its revenue by the use of coercion, by using enough violence and threat of violence on its victims to ensure they are paying the desired tribute" Rothbard, M. (1981: p.66)

\section{Introduction}

Over the last century, Venezuela's socialist and mercantilist economic system has granted privileges to a selected economic elite and institutional array which have limited government's powers. Hayek's (1945) foresight is very descriptive of Venezuela's recent course towards the establishment of a non-democratic regime that attempts against economic freedoms:

In a planned society the law must legalize what to all intents and purposes remains arbitrary action. If the law says that such a board or authority may do what it pleases, anything that board or authority does is legal - but its actions are certainly not subject to the Rule of Law. By giving the government unlimited powers the most arbitrary rule can be made legal; and in this way a democracy may set up the most complete despotism imaginable. (p.69)

We believe that institutions in Venezuela need profound reforms to enjoy a virtuous circle of sustainable prosperity (Acevedo, Cirocco, and Lorca-Susino, 2019). If individual liberties, rule of law, and citizens' empowerment - three ideas frontally opposed to government's accumulation of power - are not crucial objectives of the new political and economic structure, the country will not escape the vicious circle of backwardness in which it has been tramped for decades. Thus, every edge of analysis - political, social, economic, judicial, and administrative - is of paramount importance to achieve the virtuoso cycle and the golden goal of individual liberty and wealth. In this paper, we propose a structural reform of the current taxation system, based upon Rothbard's (1992) statement: "Taxes are parasitic and statist...invade and aggress against the rights of private property" (p.68)

In light of promoting economic freedom, we propose a new taxation system for Venezuela abiding by the principles of creating a low and simple taxation system and eradicating government's independence from taxpayers: a necessary condition to starve the government and firmly establish the rule of law and democracy (Acevedo et al,

2020; Faría, 2008). The purpose of this paper is to propose an alternative tax reform. However, we do not advance this research to the point of defining specific rates for the prevailing taxes category; thus, allowing for further research. 
We structured this paper as follows. We first present a general overview of the current state of Venezuela's tax system and how the tax system, related and not related to the oil industry, has consolidated the government fiscal independence from citizens' oversight.

Further, we introduce our structural tax reform proposal based on three pillars:

i) The municipalization of the tax system where the 335 recognized municipalities should collect and manage taxes and, in turn, support the 23 federal states, the "Distrito Capital," and the national government budget spending.

ii) The simplification of the tax system through the elimination of a number of taxes leaving just (a) consumption taxes, (b) complementary duties, (c) an emergency tax, and (d) a tax on natural resources which proceeds will be distributed among legal age Venezuelan citizens by birth physically living in the country.

iii) The introduction of several rules and regulations which are necessary to ensure the efficiency of the tax system such as limits to municipal reserves, public debt and deficits, and a referendum system to approve temporary increases of the spending limits and new taxes.

Moreover, we evaluate the feasibility of our proposed tax system in Venezuela. We highlight that our tax proposal would protect individual rights, minimize the role of the State, force the government to a transparent and auditable administration. Above all, we believe our tax proposal will help to reduce bureaucracy and eliminate pervasive incentives to join the political life for having access to the revenues obtained through the taxation system. However, we understand that this tax reform should not be accomplished in isolation but together with a massive privatization process, a constitutional amendment to eliminate the legal tender, fractional reserve system, and lender of last resort, among other reforms in which further research and proposals are required.

We conclude this work referring to, Rothbard's (1992) famous words, "unobtrusive and harmless as possible, and imitate the market as closely as it can" (p.70) that help us support our tax reform proposal and is one of its main pillars. 


\section{Venezuela's taxation system overview: A destructionist scheme of wealth}

Venezuela's constitution contemplates three taxation layers: national, regional, and municipal ${ }^{2}$. Nevertheless, the central government -national level- controls almost all three, weakening the taxation autonomy of municipal governments which end up depending on the "good faith" or discipline of the central planners' tax redistribution schemes.

The central government rules, collects and manages the bulk of the most "profitable" taxes, such as those levied on income, company assets, excise, international trade, royalties on mining and oil extraction, and other special categories. In turn, municipalities must wait for the central government to transfer funds or, what is known in Venezuela as "download the required resources", which are diluted throughout the bureaucratic network. Taxpayers, ultimately, do not enjoy the benefits of an efficient compensation in terms of high-quality services, this is the reason why Rothbard's statement, "taxation is theft," gains notorious strength.

Vera (2017) presents the evolution of taxes in Venezuela consisting of several historical stages. In this section we will present the historical evolution of taxes in Venezuela. However, given the relevance of taxes related to the oil industry, we will review the evolution of oil taxes as this is paramount to understand the urgency and importance of modernizing the current tax structure. Thus, we will first introduce a brief historical review of the tax system in Venezuela. Second, we will present the evolution of taxes related to oil industries and the rest. Third, we will present how oil fiscal revenues have evolved from concessions to the advent of mixed companies, and his analysis is summarized below. Finally, we will present a non-exhaustive review of the current taxation system.

\subsection{Venezuelan taxes over the backdrop of modern history: Non-Oil Industry Related Taxes}

Venezuela's independency process started on April 19, 1810 and ended in 1830. Back at the time, internal consumption and international trade were heavily taxed while other economic sectors such as agriculture, manufacturing, and commercial activities were not directly levied.

From 1860 to 1863 , governments increased import and export duties from $30 \%$ to more than $100 \%$. During the presidency of Guzmán Blanco (1870-1887) Venezuela simplified the tax burden on trade by almost eliminating liens on exports and reducing $70 \%$ those on imports. Besides, the government further eliminated taxes levied on transported merchandise within

\footnotetext{
${ }^{2}$ Venezuela's legal framework divides geopolitics into three levels: national, regional or state, and municipal. In the United States this division would be equivalent to, the Central or Federal Government, the state level and counties.
} 
the country. Nevertheless, governments implemented and increased stamp duties and inheritance taxes.

During the dictatorship of Juan Vicente Gómez (1908-1935), a fiscal reserve fund was created to centralize all state revenues under the public treasury and national budget figures. However, it was not until the advent of the oil boom that the taxation system and, consequently, the government revenues experienced prominent changes. On a regional basis, the legal framework of different countries began to admit and establish taxes on income around the 1920s and 1930s.

In Venezuela, the tariffs law passed in 1936 and the first income tax law in 1942 The income tax law established different rates depending on the source of incomes, based upon the type of economic activity: $1.5 \%$ on salaries and pensions, and $2.5 \%$ on industrial, mining, and commercial sales.

After WWII, Venezuela experienced the stabilization of fiscal revenues and greater "equality" that were the main justifications to implement the direct income tax. While initially introduced at low tax rates and excluded oil activities, were the prelude of the new Hydrocarbons Law of 1943.

In 1948, the government of General Marcos Perez Jimenez approved a new income tax law on mining and oil activities to guarantee a minimum participation of $50 \%$ in those industries by the state with no significant changes until 1958, when his dictatorship was overthrown, (January 23, 1958) and democratic socialism political philosophy formally started to rule Venezuela.

At the beginning of the modern democratic era in 1960's the government of Romulo Betancourt invited a group of consultants led by Carl Shoup from Columbia University. This group produced a technical report on the Venezuelan taxation system championing the increase of rates and progressivity, and the reduction of indirect taxes. It was not until 1966 when President Raul Leoni implemented some of the Shoups' recommendations.

In 1986, the government of Jaime Lusinchi modified the income tax law to include the principle of extra-territoriality which levied incomes earned abroad. This modification eliminated progressivity for companies and only two proportional rates remained, and the executive-granted exemptions. But from this moment, if Venezuelans had earned any income abroad, they had to declare and pay taxes in Venezuela.

The opening of the oil industry is the main characteristic of the 1992-1998 period. During this term, the governments of Carlos Andres Perez and Rafael Caldera (both second mandates of these politicians) applied several modifications to the taxation system, one of which was the resurgence of indirect taxes. They also established a value-added tax (VAT) at the $10 \%$ level which was later replaced by a luxury consumption tax and a wholesale sales 
tax. Another outstanding feature of this period was the governmental requirement of paying dividends, imposed upon the oil industry by Rafael Caldera. Nevertheless, given the low oil market price at the time, the general tax burden did not increase; thus, the government created a temporal bank debit tax, mainly levying debits or withdrawals made on checking and saving accounts, at the $0.75 \%$ level.

In 1999, with the advent of the "socialism of the XXI century" led by Hugo Chávez, the taxation system was modified again. He enabled a tax of $0.5 \%$ on financial transactions, replaced the wholesale sales tax with a VAT of $15.5 \%$, reformed the income tax, the inheritance tax, the stamp duties, and tariffs.

A set of enabling laws allowed Nicolás Maduro, after Chávez's official death on March $5^{\text {th }}$, 2013 , to reform the taxation system yet again to make it "less regressive" and increase money collection. From 2013, those changes focused on eliminating inflationary adjustments used in the balance sheets of financial institutions for income tax declarations. Other changes were setting a VAT surcharge of $15 \%$ for luxury goods, declaring in advance taxes on tobacco and cigarettes, increasing the tax rate imposed on alcohol from $15 \%$ to $50 \%$, increasing the income tax for financial institutions from $34 \%$ to $40 \%$, levying a tax on "big financial transactions" for "special taxpayers" of $0.75 \%$ per operation.

\subsection{Oil Revenue: Evolution and Consolidation of State's Fiscal Independence}

There is a vast number of studies that have demonstrated that the larger a country's oil reserves, the faster the destruction of its democracy and the rate of freedoms (Cesari, 2014; Hachemaoui and O'Mahony, 2012; Ross, 2012 and 2001; Tsui, 2011; Aslaksen, 2010; Collier and Hoeffler, 2009; among others). Cesari (2014) proved the negative effect of oil on democracy because it induces to economic and political distortions. Her findings are statistically significant and provide an estimation of the oil-democracy demultiplier. According to Ross $(2012,2001)$ the data shows that oil resources hurt democracy and that there tend to be a correlation between oil resources and authoritarian regimes. Tsui (2011) explains that the discovery of oil dwells of 100 billion barrels has caused a progressive loss of democratic quality of $20 \%$ during the next three decades. Collier and Hoeffler (2009) demonstrate that income from natural resource might have a negative effect on democracy and that well-endowed countries in natural resources require a solid democracy with a strong system of checks and balances.

The oil sector has, historically, been the main source of income for the Government of Venezuela; thus, we believe taxes related to this sector and its proceeds should have a thorough analysis. Fiscal income obtained by the government from the oil sector, from 1960

to 1986, represented the bulk part of the nation income which, through the 
institutionalization of populism and corruption, has undermined economic freedom as well as deteriorated democracy setting the urgency of the fiscal independence argument we defend in this paper.

The government of Venezuela enjoyed the highest degree of fiscal independency during the Yom Kippur War, and other regional conflicts, which helped increase the price of oil. Despite, the average was around $70 \%$ up to 1990 , since that year, the participation of fiscal incomes from the oil sector in the current incomes has decreased. This might be promoted for some reasons, among them: i) the decrease of oil prices; ii) despite some episodes of increase of the oil price, the decrease of the production; iii) reforms of other taxes that incremented the tax burden in non-oil sector.

Graph 1 shows the percentage that fiscal incomes, from the oil sector, represents over the current incomes.

\section{Graph 1. Fiscal Incomes Oil Sector / Current Incomes 1960 - 2015.}

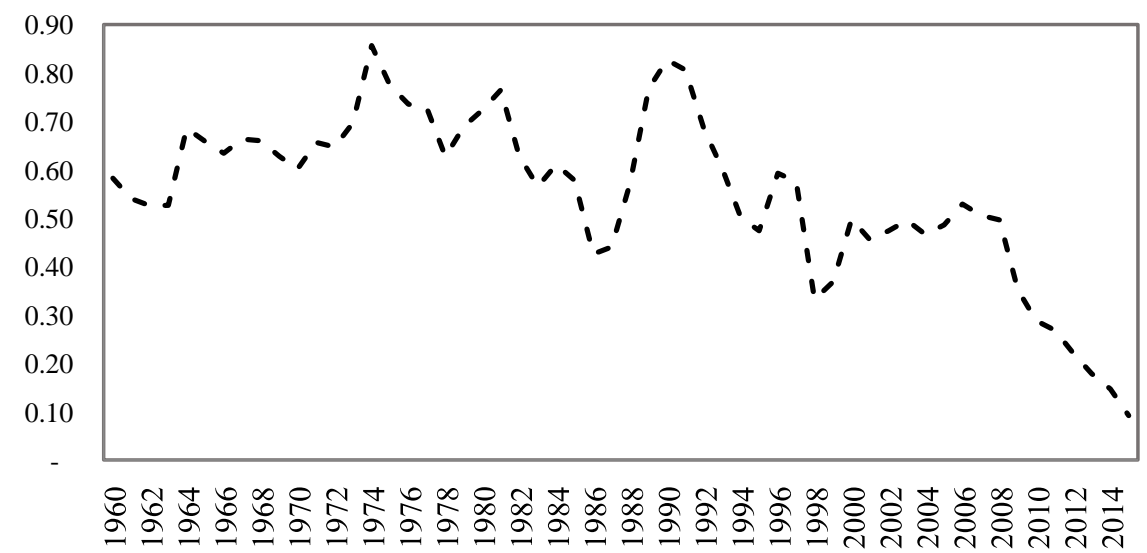

Source: Vera (2017).

This scenario was not different from specific taxes such as income tax from oil rent. Graph 2 shows the percentage that income tax represented from the oil sector the total income tax collected from 1960 to 2015. The graph below shows that in certain years, over 90\% of the total income tax collected came from the oil sector. 
Graph 2. Income Tax Oil Sector / Total Income Tax Collected 1960 - 2015.

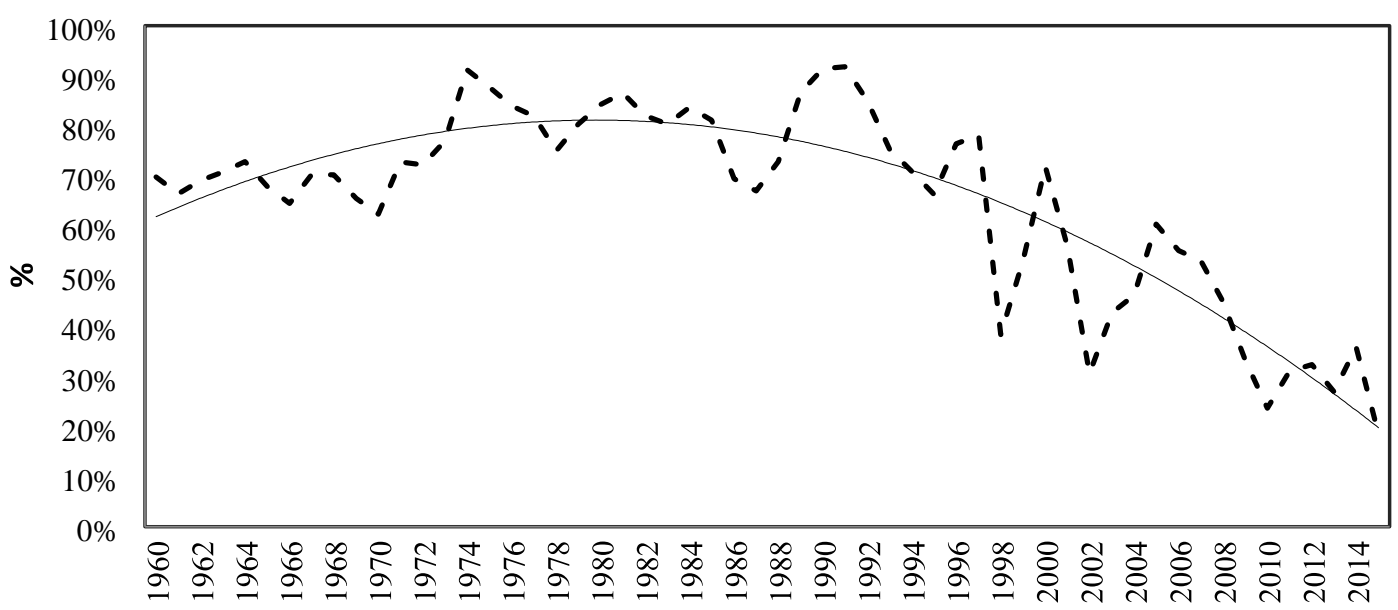

Source: Vera (2017).

Graph 3 shows that the income tax as percentage of GDP has been higher on the oil sector than on the non-oil sector. However, in 1992 Venezuela experience the "Apertura Petrolera" (the oil opening). which seems to have resulted in a decreased in the income tax as percentage of GDP on oil sector. Further the reduction that stars in 2008 could be explained as the result of the low maintenance which resulted in services disruption.

Graph 3. Income Tax as of the GDP Oil and Non-Oil Sectors, from 1960 to 2015.

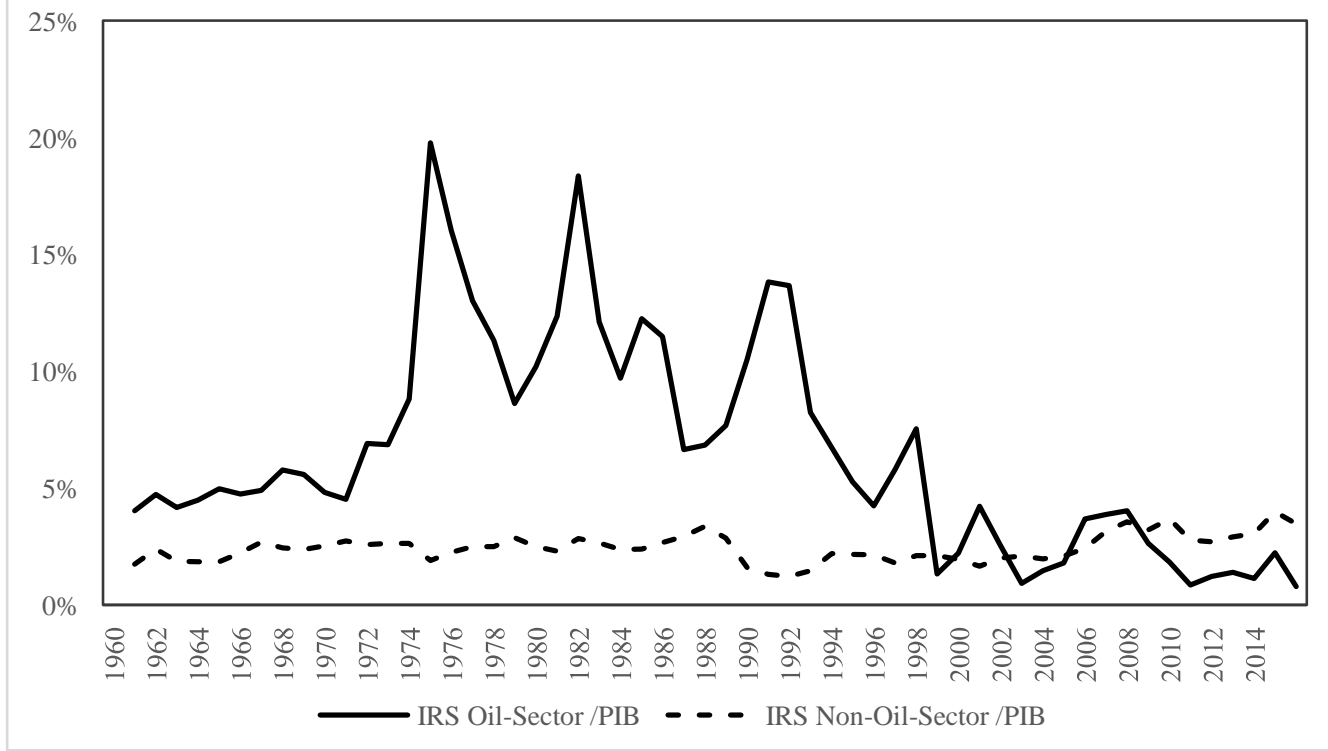

Source: Vera (2017). 
Graph 4 shows the percentage that royalties represented over fiscal incomes from 1960 to 2015 and it shows that this revenue accounts from 5\% to $40 \%$ source of income for fiscal independence for the Venezuelan Government. Under the logic of Venezuela's laws, royalties are a kind of tax that all oil companies have to pay to the State for the extraction of oil.

Graph 4. Royalties Oil Sector / Total Fiscal Income 1960 - 2015.

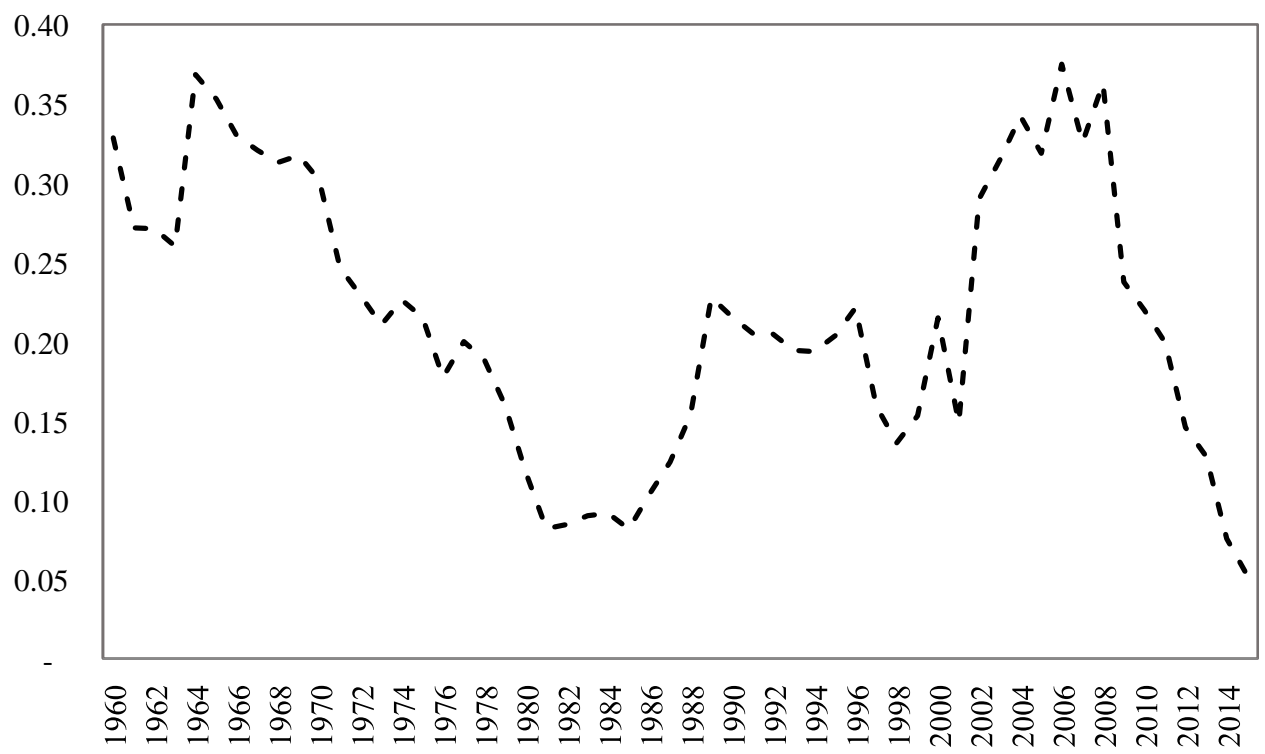

Source: Vera (2017).

\subsection{Oil Revenue: Evolution and Consolidation of Fiscal Independency}

Nevertheless, understanding the evolution of the Venezuelan oil fiscal revenues is necessary to analyze the different stages this sector has experience. For Viloria (2018) there are six well-defined stages, from concessions to the advent of mixed companies, and his analysis is summarized below.

Concessions. Starting in the 1920's, oil exploration, exploitation and export activities were possible through concessions granted by President Gómez to international companies, for periods of 20 to 40 years. After some modifications of the initial legal framework structuring the rising hydrocarbons industry, oil related revenues began to increase for the government with the implementation of surface taxes and production royalties. The Hydrocarbons Law of 1920 was the first of its kind and introduced the concept of payment of oil taxes by contract.

The Hydrocarbons Law of 1943, reformed in 1965 and in 1967, consolidated the role of the Venezuelan state as the only owner of the nation's oil resources and sole entity able to 
structure and administer oil related taxes. Such law allowed the government to retain $50 \%$ of the net profit resulting from selling the extracted oil, set production royalties at a level of $16.67 \%$, and established the following three mechanisms to exercise the right to explore, exploit, manufacture, and transport hydrocarbons:

- Directly through the government.

- Through autonomous bodies and state companies by assigning certain areas to them. Such bodies and companies could promote the creation of mixed companies.

- Through concessions to private companies, which did not imply transferring the property of the wells and had the following characteristics:

- The exclusive right to exploit oil for 40 years within the assigned tracts.

- The right to manufacture refine and transport oil up to the ports.

- Continuous exploitation for three consecutive years, without interruption.

- Termination by resignation, breach, reduction of the granted area, expiration or maturity. The corresponding tracts and its infrastructure were transfer onto the state with no compensation.

- Taxes on exploration, initial exploitation, exploitation, surface, production (in the form of royalties), manufacturing, transport, and income.

Service contracts. In 1959, the democratic socialist government of Rómulo Betancourt stopped concessions and started a regime of service contracts. In 1960, the government created the Venezuelan Petroleum Corporation (from now CVP for its name in Spanish: Corporación Venezolana de Petróleo) to achieve the following two main objectives:

- Explore, exploit, transport, trade, and exchange hydrocarbons within the country or abroad.

- Promote companies to develop the hydrocarbons commerce by contributing to their equity.

Under this new system, the state assigned contracts to CVP to initiate operations while under the concession system, the operations were organized by private companies.

The Hydrocarbons Law of 1967 introduced the legal framework for the service contracts, and granted the right to explore, exploit, refine and transport hydrocarbons to autonomous organizations and state companies. If contracts were more favorable to the nation, compared to the benefits provided by concessions, those public entities could create mixed companies. 
Right before the nationalization of the oil industry, the concession system that was introduce in the 1920's was operating alongside the new service contracts introduced by the CVP. In 1971, Rafael Caldera signed into law the Hydrocarbons Reversion Law, which mandated that all oil company assets would revert to the state once concessions times expired preluding the oil industry nationalization. President Caldera carried out a reform of the income tax in 1970, which allowed the government to unilaterally determine the price of the extracted oil to be used for income tax calculations.

Nationalization. Carlos Andrés Pérez in his first mandate signed a new Hydrocarbons Law on August 29, 1975 which came into effect on January 1, 1976. This law helped the government nationalized the oil industry at all production stage. The result of this legislation can be summarized as follows: i) the government had the right to terminate in advance concessions and service contracts (see Table 1); ii) the government had the exclusive right to engage in international trade operations; iii) all assets, but not liabilities, of companies under concessions were transferred to the states; iv) private companies were compensated; and v) the government started managing the industry.

Table 1. Scheduled expiration year of concessions.

\begin{tabular}{|c|c|}
\hline Expiration year & $\begin{array}{c}\text { Fraction of the total number } \\
\text { of running concessions }\end{array}$ \\
\hline 1983 & $8 \%$ \\
\hline 1984 & $63 \%$ \\
\hline 1985 & $11 \%$ \\
\hline 1986 & $1 \%$ \\
\hline 1988 & $8 \%$ \\
\hline 1989 & $2 \%$ \\
\hline $1990-1997$ & $7 \%$ \\
\hline
\end{tabular}

Source: Viloria (2018).

The birth of Petróleos de Venezuela S.A (PDVSA). Through public enterprises, the state would manage the main industry of the country. For this reason, the government created Petróleos de Venezuela S.A. This company acted as the headquarters of a series of subsidiaries to manage 2.5 million hectares of land containing 7,000 wells, 10,000 kilometers of oil pipelines and 12 refineries. The 14 initial subsidiaries became only three, after a complex process of administrative optimization, namely: Lagoven, Corpoven and Maraven.

The oil opening. With the purpose of assuring a stable positioning of the Venezuelan oil and its derivatives, PDVSA began an internationalization process called "the oil opening" 
starting in 1983, by partially or totally acquiring refineries and distribution and commercialization systems. PDVSA bought Citgo in USA ( 8 refineries and 16,000 gas stations), rented a refinery in Curacao, and took part in four refineries in Germany, two in UK and one in Belgium. This "oil opening" process began in 1992 and consisted of establishing strategic associations for oil production, association agreements for exploration and outsourcing for service activities with private national or international capitals.

In light of the increasing demand projections, the main objective was to expand the production capacity of hydrocarbons, to decrease the costs of exploring, extracting and operating, to improve the available information on the capacity and reserves, to open new markets and enhance existing ones, and to promote the incorporation of other productive sectors into the most important industry of the country.

To attract investors, the government modified the income tax law applicable to oil activities from $67.7 \%$ to $34 \%$. Royalties (although not considered as a tax in a formal way, they take part in fiscal revenues) were reduced to $1 \%$ for the first ten years and then adjusted to $16.67 \%$ thereafter. With these reforms, the fiscal participation of the oil sector in government's revenues decreased from $65 \%$ to around $33 \%$.

PDVSA considered three modes of operation within the context of the opening process: operating agreements, shared earnings schemes, and strategic associations.

The first model aimed at granting operating agreements to private companies for 20 years for mature or inactive oil fields. Those contractors received a monetary compensation from PDVSA per extracted barrel limited by the maximum quarterly price in USD per barrel based upon a previously agreed product basket. Those companies paid a tax rate of $34 \%$ while PDVSA owned the extracted products.

The second type of opening process was based on the idea of shared earnings granted a period of 20 years to private companies for initial exploration (three to five years of those twenty) and posterior production of light and medium crude oils. Private companies had to take all the risk involved in exploration; however, once oil was discovered, PDVSA became a shareholder with a stake of $1 \%$ to $35 \%$ of the whole equity. Nonetheless, production was distributed among the members of the consortium (private companies and PDVSA) and every member was authorized to become an independent seller. PDVSA's subsidiary company CVP managed this modality and fiscal revenues under these schemes were:

- Royalties of $16.67 \%$

- Income tax of $67.7 \%$

- Between $29 \%$ to $50 \%$ of income before taxes.

- Dividends paid to CVP according to stakes. 
The third type of opening process was the strategic associations granted by periods of 30 to 35 years for exploration and production of heavy and extra heavy crude oils in the Orinoco Oil Belt. Private companies formed consortiums with PDVSA with a stake varying between $30 \%$ and $49.9 \%$ of the whole equity.

Mixed companies. Starting 1999, the government started a process to turn all service contracts and strategic associations into mixed companies. Venezuela participated in those mixed companies with the CVP as a major stakeholder. In the process, some companies did not agree with the new conditions and sued the Venezuelan State. ${ }^{3}$

Given the new rules, fiscal revenues, coming from the oil industry, changed as follows:

1. Income tax of 50\% and a VAT, although government exempted oil companies to pay this last one.

2. Surface: equivalent to 100 tax units per squared kilometer of the assigned area.

3. Own consumption: $10 \%$ of the value of each cubic meter of produced and consumed oil in their internal operations.

4. Extraction: 1/3 of the extracted hydrocarbons, calculated upon the same basis used for royalties; the law allowed companies to discount the amounts paid as royalties or "special advantages."

5. Import registration: $0.1 \%$ of the total volume calculated upon the sale price if they export.

6. Royalties: although not considered a tax by the Organic Hydrocarbons Law in force, they represent a fiscal revenue source directly paid to the Public Treasury of $30 \%$ of the extracted hydrocarbons value, reducible to $20 \%$ for mature wells.

7. Special advantages: additional royalty of $3.33 \%$ of which $2.2 \%$ goes to the municipalities where the companies operate, plus a "shadow tax" to assure that the government of Venezuelan received 50\% of the extracted and sold hydrocarbons value.

8. Windfall: it is a tax applicable to companies exporting liquid hydrocarbons, both natural and improved, and derivatives. It consists of taxing companies depending on a benchmark price of 70 USD per barrel. If the Brent price of the moment were greater than the benchmark but less than 100 USD per barrel, the oil companies would pay 50\% of the difference to the government. If the Brent price exceeded the level of 100 USD per barrel, oil companies had to pay $60 \%$ of the difference. The collected liens would not go to the public treasury but to a national development fund (FONDEN)

\footnotetext{
3 Crystallex International Corp v. Bolivarian Republic of Venezuela, No. 18-2797 (3d Cir. 2019). ConocoPhillips v. Venezuela ConocoPhillips Petrozuata B.V., ConocoPhillips Hamaca B.V. and ConocoPhillips. Gulf of Paria B.V. v. Bolivarian Republic of Venezuela (ICSID Case No. ARB/07/30)
} 
administered by and for the central government. In 2013, the benchmark price increased to 80 USD per barrel.

\subsection{The Current Landscape: A Non-Exhaustive Review}

The tax system in Venezuela is based on the revenues obtained with income on corporate and individual bases, capital gains, consumption in the form of VAT, customs (imports, exports, and transit), excise, and inheritance. On the other hand, there are non-tax revenues which include royalties on mining and oil activities, dividends paid by PDVSA and the mixed companies of the oil sector, profits from the central bank of Venezuela, foreign exchange profits, and transfers among public bodies. Vera (2017) explained that this tax system revenue was a major concern for its lack of progressivity caused by the oil proceeds and the need to increase non-oil fiscal revenues Although we do not agree with progressivity and aim at the objective of reducing taxes in Venezuela as much as possible, we consider that the overall picture presented in his work is sufficiently descriptive of the current system. We take upon his analysis to provide a description of the major tax categories in force.

Income tax. It is levied on individuals and corporations. Article 50 of Decreto No. 2.163 (2015) establishes eight rates imposed on individual incomes for residents, expressed in tax units. $^{4}$ (Table 2). Incomes from non-resident individuals are taxed at a flat rate of $34 \%$.

Table 2. Rates for individuals based on Tax Units.

\begin{tabular}{|l|l|}
\hline \multicolumn{1}{|c|}{ Ranges in tax units (TU) } & \multicolumn{1}{c|}{ Rate } \\
\hline Up to 1,000 & $6 \%$ \\
\hline Greater than 1,000 but less than or equal to 1,500 & $9 \%$ \\
\hline Greater than 1,500 but less than or equal to 2,000 & $12 \%$ \\
\hline Greater than 2,000 but less than or equal to 2,500 & $16 \%$ \\
\hline Greater than 2,500 but less than or equal to 3,000 & $20 \%$ \\
\hline Greater than 3,000 but less than or equal to 4,000 & $24 \%$ \\
\hline Greater than 4,000 but less than or equal to 6,000 & $29 \%$ \\
\hline Greater than 6,000 & $34 \%$ \\
\hline
\end{tabular}

Source: Article 50 Decree No. 2.163, 2015.

\footnotetext{
${ }^{4}$ By the time this paper is written, a tax unit (TU) in Venezuela is equivalent to 50 bolívares soberanos (Bs.S or VES).
} 
Banks and insurance companies had to applicate a $40 \%$ rate; However, for other non-oil and non-mining corporations, article 52 of Decreto No. 2.163 (2015) sets the rates as shown in Table 3.

Table 3. Rates for banks and insurance companies based on Tax Units.

\begin{tabular}{|c|c|}
\hline Ranges in tax units (TU) & Rate \\
\hline Up to 2,000 & $15 \%$ \\
\hline $\begin{array}{c}\text { Greater than } 2,000 \text { but less than } \\
\text { or equal to 3,000 }\end{array}$ & $22 \%$ \\
\hline Greater than 3,000 & $34 \%$ \\
\hline
\end{tabular}

Source: Article 52 Decree No. 2.163, 2015.

Vera (2017) explains that taxation on capital gains is included in the income tax, while multinational companies operating in Venezuela must pay this income tax based on the income generated in country and concludes that mining and oil activities are taxed at a rate of $50 \%$.

Value-added tax. It is levied on the sale or transfer of consumable items, good imports, and the provision of services. It is a cascade tax because each stage of the productive chain transfers it on to the next stage up to the final consumer.

Article 27 of Decreto No. 1.436 (2014) set the following well-structured categories: 1) A $16 \%$ applicable to the import or sale of certain products for direct human consumption, as well as exemptions on some others; 2) A $0 \%$ on exports of consumable items and services; 3) A $15 \%$ to $20 \%$ varying tax on luxury goods and services; 4) A $0 \%$ on natural hydrocarbons sales. The executive branch can modify all those rates within the limits established by this decree.

Customs. This category includes tariffs imposed on ordinary imports as well as on the imports of postal packages and alcoholic species; these tariffs comprise customs service rates, as well as merchandise in transit and exports.

Excise. Imposed on alcoholic beverages, tobacco, cigarettes, and gambling. Rates on alcoholic beverages can vary depending on the alcoholic content and its origin (national or imported) and based on production, imports, and final consumption. It imposes a tax of $70 \%$ for cigarettes and tobacco, and $0 \%$ when these products are for export.

\footnotetext{
${ }^{5}$ Maduro's regime established a reduced rate of $8 \%$.
} 
Oil royalties. The current general rate is $30 \%$ of the oil production, but the government can decrease it to $20 \%$ for mature wells and extra heavy crude oil.

Hyperinflation. Although this is not a formal type of tax approved by congress, the inflationary tax imposes, if not the heaviest burden in the world, one of the heaviest ones on Venezuelan citizens. Inflation skyrocketed over the last 21 years, during the period known as the era of the socialism of the $21^{\text {st }}$ century under the mandates of Hugo Chávez and Nicolás Maduro. In fact, using purchasing power parity (PPP) from free and black-market exchange rates, Hanke's last calculations (2020) estimate an annual inflation rate of more than 3,270\%, the highest of the world (Table 4).

Table 4. Annual Inflation Estimated by Prof. Hanke.

\begin{tabular}{|l|l|l|l|l|l|}
\hline Country & $\begin{array}{c}\text { Free-Market } \\
\text { Exchange } \\
\text { Rate } \\
\text { (1 USD) }\end{array}$ & $\begin{array}{c}\text { Date of } \\
\text { Hanke } \\
\text { Measurement }\end{array}$ & $\begin{array}{c}\text { Hanke } \\
\text { Annual } \\
\text { Measured } \\
\text { Inflation } \\
\text { Rate }\end{array}$ & $\begin{array}{c}\text { IMF Year- } \\
\text { End } \\
\text { Inflation } \\
\text { Projection }\end{array}$ & $\begin{array}{c}\text { Hanke- } \\
\text { IMF } \\
\text { Differential }\end{array}$ \\
\hline Venezuela & $\begin{array}{l}179,222.60 \\
\text { VES }\end{array}$ & $05 / 14 / 2020$ & $3,275 \%$ & $15,000,000 \%$ & $-11,725 \%$ \\
Zts
\end{tabular}

Source: https://www.cato.org/research/troubled-currencies

However, it is important to know that high inflation is not the exclusive result of the monetary and fiscal policies implemented by Chavez and Maduro. Governments during the social democracy period (1958-1998) made reforms to strengthen central planning and increase government spending and fiscal deficit contributing to periods of high inflation. Faría and Filardo (2015) depict the major changes in the economic arena implemented during every presidential period from 1958 to 1998. Besides devaluation, one of the paramount changes associated with the high inflation was the amendment of the Central Bank Law, approved during Rómulo Betancourt's mandate to allow the central bank to lend to the government. 


\section{A structural reform to empower citizens: A minimum tax burden approach.}

We believe that Venezuela needs to implement radical institutional reforms. We defend that today's technological advancements (e.g., Blockchain and others) should be part of political and administrative processes to allow more transparent mechanisms for the people to audit and supervise these processes.

We believe that it is necessary to eliminate almost all existing taxes as well as exemptions and any other kind of "progressivity" and propose a radical overhaul of all remaining sources of fiscal revenues. Our suggested taxation system for Venezuela should rest on three pillars.

i) The municipalization of the tax system

ii) The simplification of the tax system through the elimination of certain taxes.

iii) Follow the market efficiency.

\subsection{Municipalization of the tax system.}

Municipalities are the cornerstones of our study. We believe that municipalities should receive fiscal revenues directly from taxpayers and transfer a fraction of the revenues to the states and the national government. We propose that the 335 municipalities should collect and manage taxes and, in turn, sent a percentage of that revenue to support the 23 federal states, the "Distrito Capital," and the national government budget spending. In detail, each municipality should send $20 \%$ of the total collected taxes to state government which, in turn, sends $25 \%$ of the total incomes received from all counties to the national government.

We believe that municipal governments are closer to citizens in terms of serving them. Then, we consider that this approach -bottom up-would be much more efficient than the current top-down current mechanism. This last scheme allows the national government to enjoy an exaggerated control of fiscal revenues while leaving municipalities weaker and highly dependent on the "good will" of national authorities to transfer resources.

\subsection{Simplification by Elimination}

We believe that heavy tax burdens and progressivity should be subject to either removal or drastic reduction. This simplistic approach would be feasible in the context of further deep reforms and a significant decrease of the government expenditure; thus, this proposal unfortunately cannot be applied if politicians and society insist to keep a populist spendthrift government. 
We propose maintaining the following taxes: a) consumption taxes, (b) complementary duties, (c) an emergency tax, and (d) a tax on natural resources which proceeds will be distributed among legal age Venezuelan citizens by birth physically living in the country.

This proposal promotes a country with sustainable prosperity, efficiency, and minimum government meddling in economic affairs. The unilateral elimination of all trade barriers, which includes the total removal of tariffs, customs service rates and other taxes imposed on imports, exports, and merchandise in transit within Venezuela, is the first and even fundamental step of this proposal. Our study defends the removal of the inefficiency costs of cronies who do not compete in price and quality against imported goods. We further believe that the political appetite for more revenues onto the citizens in the form of a higher cost of living, is a protectionist, unfair, and unethical practice that should be eliminated.

In addition, we promote replacing the VAT, as a form of consumption tax, for a low sales tax, without exemptions. Although our intent is to simplify and minimize the state intervention on fiscal revenue, we still consider it is necessary for Venezuela given its current conditions. That is the reason why we implement a sales tax and two additional categories.

The elimination of the income tax and capital gains on individuals and corporations (including banks and insurance companies) is another important purpose of this proposal. With this, it would be possible to establish healthier incentives to work and produce. As well as other taxes such as inheritance and capital transfers, tobacco, cigarettes, and alcohol.

\subsubsection{Taxation on consumption.}

Taxation theory explains that government can levy a consumption tax on consumption spending on goods and services. Value-Added, sales, excise, and expenditure taxes are the four most common types of taxes used tax consumption. According to OECD (2019) ${ }^{6}$ "consumption taxes accounted for $30.6 \%$ of all tax revenues in OECD countries in 2016 on average." This study further reported that OECD countries had relied increasingly on taxes on general consumption since 1972. Value-added taxes have become the largest source of revenue representing over $20 \%$ of total tax revenues in OECD countries in 2016.

Following Rothbard (2018), we lean toward the direction of a unique low and nonprogressive sales tax instead of a Value Added Tax (VAT), since the first one is less intrusive, in terms of government meddling, and less distorting of the production structure than the second one. Since the tradeoff between current and future consumption is always part of the individual preferences, Rothbard (2018) dismantles the argument that a consumption tax would not punish savings as an income tax does. However, because we are drastically simplifying the complexity of the current Venezuelan taxation scheme and reducing its burden, we consider

\footnotetext{
${ }^{6}$ OECD (2019), "Countries with VAT", in Consumption Tax Trends 2018: VAT/GST and Excise Rates,
} Trends and Policy Issues, OECD Publishing, Paris, https://doi.org/10.1787/ctt-2018-7-en. 
that a sales tax is an appropriate category to maintain, along with the other two taxes explained in this paper and in the context of our reforms program, a minimum state and a government accountable to its people.

Each municipality will have the autonomy to impose a flat rate on consumption varying from $0 \%$ to a maximum of $30 \%$ but the constitution should establish this limit. Through this discretionally, we intend to promote competition among counties to attract investments and people. Each municipality must conduct specific research to establish the rate more adequate to their own situation, necessities, and objectives.

\subsubsection{Complementary duties}

Municipalities will collect and manage all complementary duties such as stamp duties, motor vehicles (i.e., cars, trucks, aircrafts, boats, etc...) registration fees, dividends from concessions (i.e., roads, parks, etc...). All other state or central governments level complementary duties will be eliminated. In the case of stamp duties, we propose that documents should be stamped with the county stamps where the official document was issued. The national vital record office ${ }^{7}$ should be supported through the fees that municipalities collect and send to the state and national governments and using a Blockchain system that allows the validation and eliminate possible frauds.

\subsubsection{Emergencies}

We believe the National government should impose and manage a temporal tax on consumption or on bank transactions in the case of a natural disaster or any other extraordinary catastrophe. Municipalities would collect this temporal tax and send the $100 \%$ collected funds directly to the National Government. These taxes would be limited as follow: i) government can impose just one of them; ii) the tax would not last more than 3 months in a year; iii) the rate would not be more than $3 \%$ for sales and $0.5 \%$ for bank transactions; iv) the tax could not be imposed more than twice in each presidential term.

\subsubsection{Taxation on natural resources}

Traditionally, taxes, royalties and dividends paid by oil and other natural resources corporations (companies combining international capitals and the government) represent a significant source of government income which provides independence and lack of

\footnotetext{
${ }^{7}$ This office is responsible for holding personal information about registrations, and other civil acts such as natural resources royalty payment system registration, marries, divorces, born, and death registrations, among others.
} 
democratic accountability. These are, therefore, not directly extracted from the pockets of the citizens, the ultimate taxpayers.

Within the context of the privatization process of all state-owned companies and assets, suggested by Acevedo, Cirocco, and Lorca-Susino (2019), we propose the equal distribution of all oil proceeds among Venezuelans by birth and of legal age (18 years). The aim of this proposal rest on the idea that removing the direct tax collection authority from the government of Venezuela will deny it from a massive source of revenue which is currently providing the government with much independence to implement regime-friendly fiscal and monetary policies. Thus, the main purpose if to remove such source of political independence for the government. By limiting the economic power of the government and making it totally dependent -in fiscal terms- on its citizens, the civil society would have a lauder voice to demand services of higher quality, and an appropriate check-and-balance mechanism. The same distribution procedure would take place, by virtue of this reform, in all other natural resources industries such as iron, natural gas, coal, etc.

Nowadays, oil proceeds mostly consist of the items listed in subsection 2.1.1 of this paper, under the subtitle of Mixed companies. Our proposal is to simplify the tax system scheme by allowing a reasonable type of royalty on production, and exploration just applicable for natural resources companies. Companies would pay the royalty through a bank system —we proposed using the Blockchain - and funds would be equally distributed and deposited in the accounts of all Venezuelans by birth and aged 18 years or older, in US dollars or any other sound or stable currency. The exact same reasoning described here for the oil business would apply for the other natural resources industries.

In addition, dividends should go directly to the citizens and companies holding shares of the business, by definition ${ }^{8}$. It is worth remembering that, as part of the privatization process mentioned earlier as the main context of our new tax system, Venezuelan citizens would take part in the oil business (and in all-natural resources businesses) by receiving a fraction of its total shares.

As we envision this tax as a kind of price that producers should pay to Venezuelans for the exploitation of a natural resource, we propose that free-market forces must establish the specific rates for the natural resources tax. As a benchmark, we suggest the average of those rates imposed in other countries. For example, graph 4 is from the Annual Statistic Bulletin of OPEC (2019) and shows the composite barrel and its components.

From there it is easy to estimate the tax burden on oil barrel. The UK, the highest, in 2018 taxed each barrel on approximately 61.3 percent, while in the USA, the lowest, is around

\footnotetext{
${ }^{8}$ We do not suggest a kind of oil fund such as in Norway and other countries as history has demonstrated that in Venezuela institutions and politicians do not share the same understanding of regulation as the representatives from those countries. Moreover, Venezuela has had already that kind of funds, but politicians have squandered them.
} 
19.7 percent. Then a good starting rate could be the average of the two or three higher and the two or three lower rates, in this example for 2018 would be around a 35 percent for each oil barrel produced ${ }^{9}$.

\section{Graph 4. Composite barrel and its components percentage.}

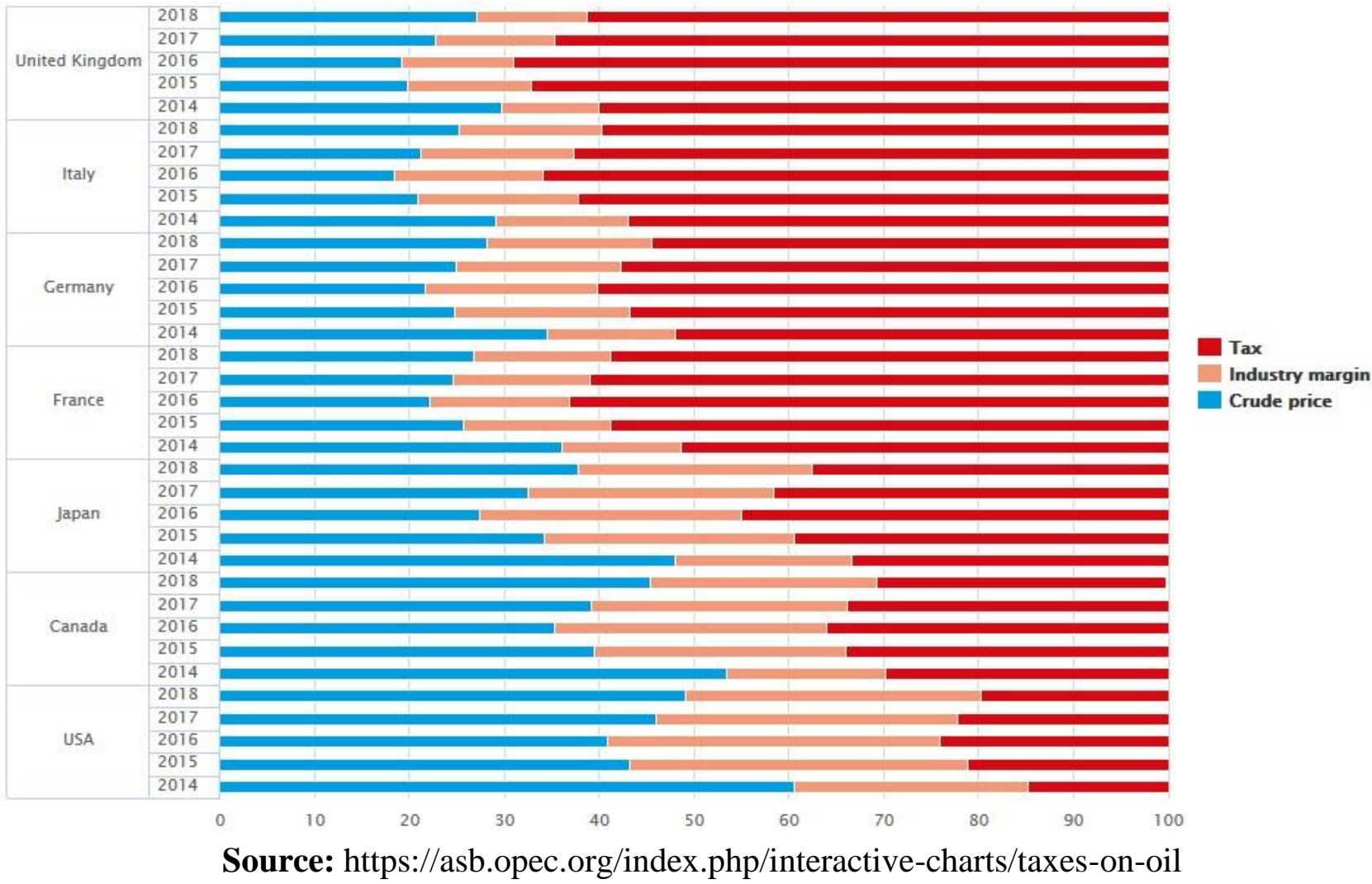

Cirocco (2019) explains and refutes the main arguments used by the detractors of this specific reform to discredit it, by differentiating it from populist proposals emerging from the own government and the so called official "opposition" in Venezuela. Our reform implies a structural and profound change that has nothing to do with such palliatives and superficial attempts disseminated with electoral purposes.

\footnotetext{
${ }^{9}$ We are not saying that this is the real starting rate of our proposal. For establishing this starting rate, it is necessary further research and deep analysis of the international market of the specific natural resource at the immediate moment to be applied, otherwise we would be forecasting the market behavior based on historical data and despite it is relatively easy using some estimation techniques, that is a task that we prefer to leave for social engineers and Keynesians and that it would not be pertinent in a research paper with an Austrian Economics approach. After the initial rate, it should fluctuate depending on the international market.
} 


\subsubsection{Alaska: A comparative case study}

Alaska is the only exception in the United States confederation where subsurface mineral resources are owned by the state. However, it is often categorized as a successful case of natural resource management as the oil market allows the participation of its residents in the production business. For this reason, we believe this system is worthy of being replicated.

Alaska Department of Revenue Tax Division (2019) explains sources of income and spending restrictions that the Alaskan government typically faces described in its official report as the following:

1) The government receives four types of revenues: oil, non-oil, federal, and investment. Oil revenues come from royalties and taxes on production, ownership and corporate income charged to oil and gas exploration and exploitation companies in Alaskan territory. Non-oil revenues come from a series of taxes, rents and royalties charged to nonoil companies, licenses, permits, fines, confiscations, and service charges. The federal taxes come from federal government transfers for specific purposes, such as road repair, school support, and the Medicaid program. Finally, investment revenues are the result of the profits generated by certain state assets.

2) A fraction of the total income is considered unrestricted from the point of view of the use that the government may give it while the other fraction is considered restricted because it must be used for specific purposes, as provided for in the Alaska Constitution, in its laws, in federal law, in historical practices or designated to honor debt commitments. In 2019, 48\% of total income was formally classified as unrestricted and $52 \%$ was classified for restricted.

3) The Alaskan government is responsible for managing various state assets, essentially investment funds, from which profits draw money to cover commitments. Table 5 shows the value of each of the major funds in 2019 and their expected long-term returns, according to Callan Associates, Inc. 
Table 5. Investment Funds of the Alaska government

\begin{tabular}{|l|l|l|l|}
\hline \multicolumn{1}{|c|}{ Acronym } & \multicolumn{1}{|c|}{ Name } & \multicolumn{1}{|c|}{$\begin{array}{c}\text { Assets value } \\
\text { (millions USD) }\end{array}$} & $\begin{array}{c}\text { Long-term } \\
\text { expected } \\
\text { return }\end{array}$ \\
\hline APF & Alaska Permanent Fund & $66,300.3$ & $7.00 \%$ \\
\hline CBRF & $\begin{array}{l}\text { Constitutional Budget Reserve } \\
\text { Fund }\end{array}$ & $1,963.9$ & $3.01 \%$ \\
\hline GeFONSI I & $\begin{array}{l}\text { General Fund and Other Non- } \\
\text { Segregated Investment - Pool I }\end{array}$ & $1,513.8$ & $2.65 \%$ \\
\hline GeFONSI II & $\begin{array}{l}\text { General Fund and Other Non- } \\
\text { Segregated Investment - Pool II }\end{array}$ & $1,449.4$ & $3.30 \%$ \\
\hline PSTF & Public School Trust Fund & 698.8 & $6.58 \%$ \\
\hline
\end{tabular}

Source: Alaska Department of Revenue - Tax Division (2019).

4) For decades, the Alaska Permanent Fund (APF) has been the state's largest asset. It receives a portion of all total royalty revenue from the oil, gas, and other minerals industries; thus, it has been the main source of financing for the annual dividends that Alaskan residents receive (Permanent Fund Dividend Program). The Constitution and Alaskan laws state that $25 \%$ or $50 \%$ of total royalty income must be deposited in the APF, while another $0.5 \%$ must be deposited with the Public-School Trust Fund (PSTF).

The Constitutional Budget Reserve Fund (CBRF) - the state's second largest asset - was created in 1990 and receives tax, royalty payments and settlements in audit or dispute between the state and production companies, after deducting $25 \%$ or $50 \%$ corresponding to the fraction to go to the APF.

5) The main state savings funds are CBRF and APF, constitutionally established. There is also, for this purpose, the Statutory Budget Reserve Fund (SBRF), created in 1986 by the legislature. The balance sheets and profits of these funds may be taken to cover government obligations, after meeting the conditions set out in Table 6. 


\section{Table 6. Conditions}

\begin{tabular}{|l|l|l|}
\hline \multirow{2}{*}{ Fund } & \multicolumn{2}{|l|}{ Conditions to approve the appropriation for any purpose } \\
\cline { 2 - 3 } & Earnings & Principal balance \\
\hline APF & $\begin{array}{l}\text { Simple majority vote of the } \\
\text { Legislature }\end{array}$ & $\begin{array}{l}\text { Requires an ammendment of } \\
\text { the Constitution }\end{array}$ \\
\hline CBRF & $\begin{array}{l}\text { Three-fourth vote of each body of the } \\
\text { Legislature }\end{array}$ & $\begin{array}{l}\text { Three-fourth vote of each } \\
\text { body of the Legislature }\end{array}$ \\
\hline SBRF & $\begin{array}{l}\text { Simple majority vote of the } \\
\text { Legislature }\end{array}$ & $\begin{array}{l}\text { Simple majority vote of the } \\
\text { Legislature }\end{array}$ \\
\hline
\end{tabular}

6) Traditionally, a portion of the APF's profits is used to pay dividends to residents. As of fiscal year 2019, a portion of such earnings is classified as unrestricted income and is used not only to cover dividends but also to finance public spending, in response to the fall in crude oil prices internationally. In 2019, that share of such earnings amounted to \$2,722.6 million.

This model has proven to procure participation of citizens and residents in the business of natural resource production by means of its dividend distribution program, government management of investment funds, support for services such as education and health, and of legislative control. However, we consider that this model could not be replicated in Venezuela. It would be incompatible with the objective of achieving limited and responsible government for the Venezuelans. Further, economic, and political institutions are embedded in a political culture which is not inducive to promote government independence and directionality for administering these funds.

\subsection{Imitate the market as much as possible.}

We understand that any taxation system tends to empower the State and affects the citizen. Our tax proposal will force the State to compete in the market where to obtain economic resources it will have to offer quality services to the citizens. The idea of "municipalization" described above will help competition among municipalities offering a lower level of consumption taxes, complementary duties and offering high quality services. Our proposal empowers citizens to control the State which will be subject to citizens demands and allowing for easy government audits to foster a true, healthy, and sustainable democracy and free market economy.

To implement this proposal, Venezuela requires strong free-market oriented reforms as those proposed in Acevedo (2019). Some Eastern European countries, like Georgia and Poland, 
have succeed applying such as kind of reforms that many western economists called "shock policies." Venezuela needs these kinds of "shock policies" to change the whole system; otherwise, any reform will certainly fail. We strongly believe that "freeing only a few areas at a time will only impose continuous distortions that will cripple the workings of the market and discredit it in the eyes of an already fearful and suspicious public" (Rothbard, 1992: p. 66). We defend that no plan will bring effective results if applies progressivism, interventionism, and partial liberalization rather than real free-market reforms such the ones we propose.

For that reason, we believe that the new taxation system proposed should be complemented by other reforms for monetary freedom, privatization of state-owned enterprises and assets ${ }^{10}$, privatizations of the healthcare and education system, a new government structure fully municipalized, decentralized, and collegiate similar to the government structure enjoyed in Switzerland. We also think that it is required a constitutional arrangement to protect the spontaneous order such as the right of citizens to organize them and offer any service that the State is not offering with the quality people wants, specific requirements to split oversized municipalities, and the possibility of cessions of Municipalities. We understand that the success of this taxation system requires some of those reforms to ensure that nothing intervenes in the natural flow of free markets, in this article we briefly explain what we think are the most important for this proposal. However, these, as well other, reforms should be addressed and depth in further research.

\subsection{Some Required Reforms}

Municipal Reserves: We propose that if municipalities generate fiscal surpluses, these could be accumulated and saved in certified reserves deposited in renowned international banks in the form of gold, silver, or other kinds of sound money. It is easier to audit a reserve at the municipal level that at a country-level. Each municipality, in turn, could distribute reserves among different specific budgets: natural disasters, backing of loans received and - evenbacking of their own municipal currency or cryptocurrency. But every specific reserve will be tied to a very particular objective, and resources will be prohibited to be diverted for other purposes. For the case of reserves intended to back municipal currency issuing, the local government could use them right after a previous decrease of their own money in circulation, with the intent to protect its purchasing power.

Public expenditure, debt level, and annual budget deficit limit: We believe that it would be necessary to implement a law that limits public expenditures, government debt and annual budget deficit following the case of Georgia (Lawson and Powell, 2019). We consider that even further measures should be needed, we think that given the Venezuela's situation, it

\footnotetext{
${ }^{10}$ See Acevedo, Cirocco, and Lorca-Susino (2019)
} 
should be necessary include fiscal limits in the constitution to avoid possible manipulations and changes of the law.

We specifically propose an annual government spending limited to $25 \%$ of the Gross Domestic Product (GDP) which could only be overridden with Parliamentary approval in case of natural disasters and other catastrophes occurs in a specific year, and just for a specific year. We propose further fiscal controls. We believe that all levels of government (central, regional, and municipal) can borrow from any national or international organization to finance their projects. However, under no circumstance any level of government could borrow an amount representing more than twice the average of the last three years of fiscal incomes. Neither could any level of government borrow an amount that will increase the public debt more than four times of the last three years of fiscal incomes.

Finally, the limit of the annual budget deficit at any government level should be no more than $10 \%$ the average of the last three years of fiscal incomes. All officers of the governments must oversee the accomplishment of these limitations. If any level of government breaks the limits, its main officers would be prosecuted for corruption, mismanagement of public funds, bad practice in public administration, and seized all their properties.

Referendums: Switzerland has a wide referendum system when it comes to implementing new taxes and social assistance. Our proposal includes such as system because shifts the decision of increasing, the time frame, and the approval of taxes to who are precisely the taxpayers, the citizens. This proposal gives the decision-making power to individuals and they would decide whether allow any proposal that directly or indirectly involves taxes. Thus, if the central government or any municipality needed to increase the rates above the maximum, impose a new tax or keep the temporary tax for more than 3 months, they would have to call for a referendum specifying rates and terms for the citizens to decide. The central government and/or municipality would not be able to impose or increase a tax if people disapprove it.

\section{Caveats and Closing Remarks}

We have analyzed the structure of the tax system in Venezuela using the Austrian School Approach which is a challenge for three reasons.

First, we have paid much attention to the quality and presentation of our numerical data to make sure it conveyed the information of the ideas we were presenting. In addition, this article presents the evolution of modern times tax and oil income which has granted to the State a fiscal independence, which has promoted the undermining of economic freedom and progressive deterioration of democracy as well as other relevant institutions. Thus, this research contributes to the scientific literature embedded in the Austrian applied economics spirit because it proposes a taxation system following the suggestions of one of the more controversial but also clear modern Austrian economist, Murray Rothbard. 
Second, we have kept a neutral political position at all time because our objective was to develop an academic article that proposes a taxation system following the Austrian School approach rather than just a policy proposal with the intention of catching the attention of any politician. However, we are conscious that despite its benefits it is very likely that our proposal will not be implemented, at least in Venezuela, because it restricts State's fiscal independence and eradicates the possibility that governments continue applying populist policies and boosting central planning.

Third, our tax proposal can be applied to any country as it helps to limit the tax burden and will promote a free market economy. Municipalities charging high taxes would be accountable to provide high quality services to taxpayers. Some Austrian economist scholars could argue that this would result in a sort of "cartelization" where municipalities could collude to keep high tax rates while maintaining a low-quality service. However, if this were possible, citizens and businesses would be free to move to the municipality offering the best, or at least the less bad, quality of services in return for the amount paid in taxes. Thus, we believe that municipalities will eventually adjust tax rates and/or quality of services to stop the exodus of citizens and businesses.

Finally, we know that this tax proposal could be implemented once citizens realize the need and urgency of a tax system that promotes the right and lowest fiscal pressure. According to our research, this will be possible if real free-market reforms are applied.

Hence, as this is just a part of a macro-proposal that follows the Austrian Economic School, we can conclude citing Rothbard (1992) to state that this new taxation system is as "unobtrusive and harmless as possible and imitate the market as closely as it can" (p. 70).

\section{References}

Acevedo, R. (2019). Prosperity and Liberty: What Venezuela Needs. Econintech.

Acevedo, R., Faría, H., Montesinos, H., and Navarro, C. (2020). "The Quality of Democracy and Governments Fiscal Dependency". Econintech's Series Working-Papers.

Acevedo, R., Cirocco, L., and Lorca-Susino, M. (2019). How to Desocialize Enterprises: A Privatization Program for Venezuela. The Quarterly Journal of Austrian Economics, 22 (2), pp. 271-297.

Alaska Department of Revenue - Tax Division. 2019. Revenue Sources Book Fall 2019. Rev. December 18, 2019. Retrieved from: www.tax.alaska.gov.

Aslaksen, S. (2010). Oil and Democracy: More than a cross-country correlation? Journal of Peace Research, 47 (4), 421-431 
Cesari, A. (2014). Oil and Democracy. Rivista Internazionale di Scienze Sociali, 122 (3), $265-274$

Cirocco, L. (2019). The Genesis of Evil, pp. 17-25 in Prosperity and Liberty, What Venezuela Needs, ed. Rafael Acevedo. Econintech.

Collier, P., \& Hoeffler, A. (2009). Testing the neocon agenda: Democracy in resource-rich societies. European Economic Review, 53 (3), 293-308.

Decreto No. 2.163. Gaceta Oficial de la República Bolivariana de Venezuela, Caracas, Venezuela, 30 de diciembre de 2015.

Decreto No. 1.436. Gaceta Oficial de la República Bolivariana de Venezuela, Caracas, Venezuela, 18 de noviembre de 2014.

Faría, H. (2008). Hugo Chávez Against the Backdrop of Venezuelan Economic and Political History. The Independent Review, 12 (4), 519-535.

Faría, H., \& Filardo, L. (2015). Venezuela: Without Liberals, There Is No Liberalism. Econ Journal Watch, 12 (3), 375-399.

Hachemaoui, M., \& O'Mahony, M. (2012). Does rent hind democracy? A critical review of the "rentier state" and "Resource curse" theory. Reveu Franceise de Science Politique, 62 (2), 1-24

Hanke, S. (2020). The Troubled Currencies Project, Cato Institute - Johns Hopkins University. Retrieved on 07/15/2020. https://www.cato.org/research/troubledcurrencies.

Hayek, F. (1945). The Road to Serfdom. London: The Institute of Economic Affairs.

Lawson, R. \& Powell, B. (2019). Socialism Sucks: Two Economists Drink Their Way Through the Unfree World. USA: Regnery Publishing.

Ross, M. (2001). Does Oil Hinder Democracy? World Politics, 53 (3), 325-331 (2012). The Oil Curse: How Petroleum Wealth Shapes the Development of Nations. Princeton: Princeton University Press.

Rothbard, M. (1981). The Myth of Neutral Taxation. The Cato Journal, Fall, 519-564. . (1992). How and How Not to Desocialize. The Review of Austrian Economics, 6 (1), 65-77 . (2018). “The Consumption Tax: A Critique.” Mises Daily Articles, January 13. https://mises.org/library/consumption-tax-critique 
Tsui, K. (2011). More Oil, Less Democracy: Evidence from Worldwide Crude Oil Discoveries. The Economic Journal, 121 (551), 89-115

Vera, L. (2017). La tributación en Venezuela: desafíos con sentido de equidad. Bogotá: Bibliothek der Friedrich-Ebert-Stiftung.

Viloria, E. (2018). "Cien años de la industria petrolera venezolana: de las concesiones a las empresas mixtas." pp. 73-88 in Crónica de una destrucción: concesión, nacionalización, apertura, constitucionalización, desnacionalización, estatización, entrega y degradación de la industria petrolera, ed. Allan Brewer Carías. Universidad Monteávila - Caracas: Editorial Jurídica Venezolana. 